\title{
Locus of Control - A Dental Student Perspective
}

\author{
Othman Wali ${ }^{1}$, Shanthi Vanka ${ }^{2}$, Amit Vanka $^{3}$, Nouf Alamoudi ${ }^{4}$
}

1, 2, 3, 4 Dentistry Program, Ibn Sina National College for Medical Studies, Jeddah, Saudi Arabia.

\section{ABSTRACT}

\section{BACKGROUND}

Students from various backgrounds and places join graduation courses in Dentistry. The environmental influence on them is varied. Academic self-concept also has been found to be a significant predictor of students' academic achievement in the college resulting in an increase in the grade point average of the students. This study was conducted to examine the relationship between the student and their academic relationship to the environment in the dental school which is the internal and external locus of control.

\section{METHODS}

This is a cross-sectional study. The method of collection of data is through a questionnaire. The questionnaire had details related to the demographic data of gender and year of study in the dental school. Questions on locus of control have been adapted from the Rotter's Locus of Control Scale. Statistical analysis was conducted using IBM SPSS version 23. Chi square test was used to test the associations between the variables and a value of $<0.05$ was considered statistically significant.

\section{RESULTS}

402 participants including students from $2^{\text {nd }}$ year to internship filled the survey questionnaire. In general, majority of the participants displayed a higher external locus of control.

\section{CONCLUSIONS}

The study participants who responded showed more external locus of control compared to the internal locus of control. Strategies should be planned and tailored to improve student support and student education. They should include a very comprehensive orientation to the students including both long term and short-term objectives.

\section{KEY WORDS}

External Locus of Control, Internal Locus of Control, Cross Sectional Study
Corresponding Author: Dr. Shanthi Vanka, Ibn Sina National College for Medical Studies, Jeddah, Saudi Arabia.

E-mail: shanthiamit@rediffmail.com

DOI: $10.14260 / j e m d s / 2021 / 124$

How to Cite This Article:

Wali O, Vanka S, Vanka A, et al. Locus of control - a dental student perspective. J Evolution Med Dent Sci 2021;10(09):573576, DOI: $10.14260 /$ jemds/2021/124

Submission 02-10-2020,

Peer Review 15-12-2020,

Acceptance 21-12-2020,

Published 01-03-2021.

Copyright (c) 2021 Othman Wali et al. This is an open access article distributed under Creative Commons Attribution License [Attribution 4.0 International (CC BY 4.0)] 


\section{BACKGROUND}

Students from various backgrounds and places join graduation courses in dentistry. The environmental influence on them is varied. It details about the various dimensions that are present in a personality which will help in explanation of their behaviour. 1,2 Evidence related to locus of control supports that it is related to the academic environment of the students. ${ }^{3}$ The locus of control is about how much control he or she has over events in his or her life.4,5 Locus of control is about the person's perception about the causes of success or failure in his / her life.5,6 When individuals believe that their success and failure are due to factors within their control, they are viewed as having an internal locus of control. If individuals most often believe their successes and failures are due to something outside of their control they are regarded as having an external locus of control. Locus of control is explained to be any person's tendency to being controlled either internally or externally. Many studies have concluded that locus of control or person's belief are about how much control he or she has over events in his or her life.5,7 It is very essential for us to assess the students inclination towards external or internal locus of control to plan strategies to improve the academic self-concept of students to be successful in and outside a dental college. ${ }^{8}$ Academic self-concept also has been found to be a significant predictor of students' academic achievement in the college resulting in an increase in the grade point average of the students. People with internal locus of control get influenced majorly by the outcomes of the workplace on the contrary people with external locus of control understand that the outcomes may be due to external stimuli and forces like luck, chance and fate. ${ }^{9,10,11}$

There was a hypothesis for the study determined (alternative hypothesis)

1. Hypothesis 1: There will be a significant difference between the external and internal locus of control and the year of study of the students

2. Hypothesis 2: There will be a significant difference between the external and internal locus of control and the gender of the students

This study was conducted to examine the relationship between the students and their academics to the environment in the dental school which is the internal and external locus of control.

\section{METHODS}

This is an analytical cross-sectional study. The method of collection of data was through a questionnaire. The questionnaire had the details related to the demographic data of gender and year of study in the dental school. The questions on locus of control have been adapted from the Rotter's Locus of Control Scale. The questionnaire has been modified as per the student's responses in the dental school after pilot testing the questionnaire on a sample of students. The final questionnaire has 27 questions with two options each. The student has to choose the best one option from the choices given to them. The two options were coded as $\mathrm{A}$ and $\mathrm{B}$. The analysis of the results is taken as external locus of control if $A$ score is high compared to the B option and internal locus of control if A score is low compared to the B option. ${ }^{12}$

The questions included details about the following points:

1. Reason for the students getting into trouble

2. Result of the unhappy things in students' lives

3. Politics

4. Respect given to the students

5. Teachers being unfair

6. Leadership quality

7. Getting along with others

8. Relationship between heredity and one's personality

9. Students trust in fate

10. Results of exams

11. Hard work and success

12. Planning

13. Person's character

14. Luck

15. Ability to be lucky

16. Accidental happenings

17. Willingness to accept mistakes

18. Nice character of the students

19. Misfortunes

20. Politics in dental office

21. Grading by the teachers

22. Good leader

23. Influence over the things happening around the students

24. Lonely feeling

25. Athletics in the dental school

26. Control over life

27. Behaviour of politicians

The reliability of the questionnaire was assessed using Cronbach alpha and after determining the test value was 0.85 . The questionnaire was distributed to the students during their free time and sufficient time was given to them to fill the questionnaire. The hard copy of the questionnaire was distributed to the students and a written consent was taken from them before they filled the questionnaire. The inclusion criteria of the study was all the students who gave a consent to participate in the study. The exclusion criteria for the study was all the students who did not agree to participate in the study and those who were not present on the day the questionnaire was distributed.

Ethical approval was taken from the Ethical Committee of Ibn Sina National College for Medical studies. All the students of Ibn Sina National College; Dentistry program available on the day of distributing the questionnaire were included in the study.

\section{Statistical Analysis}

The statistical analysis was conducted using IBM SPSS version 23. Frequencies and percentages were calculated for the dependant and independent variables. Chi square test was used to test the associations between the dependant and the independent variables. Probability value of $<0.05$ was considered statistically significant for the study. The power of the study was determined to be $80 \%$. 


\section{RESULTS}

The participants of the survey questionnaire were 402 which included the students from $2^{\text {nd }}$ year to internship. The responses included: $2^{\text {nd }}$ year students $61(15.2 \%), 3^{\text {rd }}$ year students $58(14.4 \%), 4^{\text {th }}$ year students $70(17.4 \%), 5^{\text {th }}$ year students $95(23.6 \%), 6^{\text {th }}$ year students $44(10.9 \%)$ and internship students 74 (18.4\%). The details of the year of the study of the students versus the external and internal locus of control is been detailed in the table 1 . There were 232 (57.7 $\%)$ students who responded to have external locus of control with 33 (8.2\%) second year students, 31 (7.7\%) third year students, 49 (12.2\%) fourth year students, 56 (13.9\%) fifth year students, 19 (4.7\%) sixth year students and $44(10.9 \%)$ interns. And there were 170 (42.3\%) students who responded to have internal locus of control with $28(7 \%)$ second year students, 27 (6.7\%) third year students, 21 (5.2\%) fourth year students, $39(9.7 \%)$ fifth year students, $25(6.2 \%)$ sixth year students and $30(7.5 \%)$ interns.

Overall general majority of the participants displayed a higher external locus of control compared to the internal locus of control. Table 2 revealed the responses of the gender versus external and internal locus of control. Table 2 describes that the female participants are 299 (74.4\%) and male participants are 103 (25.6\%). External locus of control was seen among 175 (43.5\%) females as compared to 57 (14.2\%) males. Comparing the locus of control of both the year of study and gender did not reveal a significant difference. The hypothesis for the study determined (alternative hypothesis) was rejected.

\begin{tabular}{|c|c|c|c|}
\hline Year of Study & $\begin{array}{c}\text { External Locus } \\
\text { of Control }\end{array}$ & $\begin{array}{c}\text { Internal Locus } \\
\text { of Control }\end{array}$ & Total \\
\hline \multirow[t]{2}{*}{$2^{\text {nd }}$ year } & 33 & 28 & 61 \\
\hline & $54.1 \%$ & $45.9 \%$ & $100.0 \%$ \\
\hline$\%$ of total & $8.2 \%$ & $7.0 \%$ & $15.2 \%$ \\
\hline \multirow[t]{2}{*}{$3^{\text {rd }}$ year } & 31 & 27 & 58 \\
\hline & $53.4 \%$ & $46.6 \%$ & $100.0 \%$ \\
\hline$\%$ of total & $7.7 \%$ & $6.7 \%$ & $14.4 \%$ \\
\hline \multirow[t]{2}{*}{$4^{\text {th }}$ year } & 49 & 21 & 70 \\
\hline & $70.0 \%$ & $30.0 \%$ & $100.0 \%$ \\
\hline$\%$ of total & $12.2 \%$ & $5.2 \%$ & $17.4 \%$ \\
\hline \multirow[t]{2}{*}{$5^{\text {th }}$ year } & 56 & 39 & 95 \\
\hline & $58.9 \%$ & $41.1 \%$ & $100.0 \%$ \\
\hline$\%$ of total & $13.9 \%$ & $9.7 \%$ & $23.6 \%$ \\
\hline \multirow[t]{2}{*}{$6^{\text {th }}$ year } & 19 & 25 & 44 \\
\hline & $43.2 \%$ & $56.8 \%$ & $100.0 \%$ \\
\hline$\%$ of total & $4.7 \%$ & $6.2 \%$ & $10.9 \%$ \\
\hline \multirow[t]{2}{*}{ Internship } & 44 & 30 & 74 \\
\hline & $59.5 \%$ & $40.5 \%$ & $100.0 \%$ \\
\hline$\%$ of total & $10.9 \%$ & $7.5 \%$ & $18.4 \%$ \\
\hline \multirow[t]{2}{*}{ Total } & 232 & 170 & 402 \\
\hline & $57.7 \%$ & $42.3 \%$ & $100.0 \%$ \\
\hline$\%$ of total & $57.7 \%$ & $42.3 \%$ & $100.0 \%$ \\
\hline
\end{tabular}

\begin{tabular}{|cccc|}
\hline Year of Study & $\begin{array}{c}\text { External Locus } \\
\text { of Control }\end{array}$ & $\begin{array}{c}\text { Internal Locus } \\
\text { of Control }\end{array}$ & Total \\
Male & 57 & 46 & $\mathbf{1 0 3}$ \\
\% of total & $55.3 \%$ & $44.7 \%$ & $\mathbf{1 0 0 . 0} \%$ \\
Female & $14.2 \%$ & $11.4 \%$ & $\mathbf{2 5 . 6 \%}$ \\
\% of total & 175 & 124 & $\mathbf{2 9 9}$ \\
Total & $58.5 \%$ & $41.5 \%$ & $\mathbf{1 0 0 . 0} \%$ \\
& $43.5 \%$ & $30.8 \%$ & $\mathbf{7 4 . 4} \%$ \\
\% of total & $\mathbf{2 3 2}$ & $\mathbf{1 7 0}$ & $\mathbf{4 0 2}$ \\
\hline & $57.7 \%$ & $42.3 \%$ & $\mathbf{1 0 0 . 0} \%$ \\
& $57.7 \%$ & $42.3 \%$ & $\mathbf{1 0 0 . 0} \%$ \\
\hline & Table 2. Gender of the Students versus \\
External and Internal Locus of Control \\
\hline
\end{tabular}

\section{DISCUSSION}

The study is aimed to assess the association between locus of control of dental students and the relationship to their academic environment. A questionnaire was administered to obtain students demographic details and locus of control assessment.

Rotter internal and external locus of control scale was used to assess students' perception. Internals have more control of the environment and tend to handle stress differently than externals. ${ }^{13}$ This study helps to focus on the framework of inquiry that has been long neglected in economic education as in the study by Ahmed A Kader. ${ }^{13}$ The importance of this study is that it helps to quantify the attributes in student motivation and academic achievement.

The results of the current study have shown an indication towards external locus of control. Externals worry more about the expected outcome. The study results are in line with the study by Fredric Linder which shows there was no statistical significance between demographic variables and locus of control which is similar to our study. ${ }^{14}$

Externals respond to stress emotionally and withdraw from stressful situations as compared to the internals who are more adaptive to stress and attempt to reduce it through problem solving strategies. ${ }^{15,16}$ The students who show internal locus of control pursue deep learning strategies as compared to the students showing external locus of control. This is also reflected with respect to the terms of learning material and learning outcomes. ${ }^{13}$ The present study did not present with any findings showing a statistical difference between males and females responses which is in line with a study conducted in Gulbarga city by Naik AR. ${ }^{18}$ Studies by Meghan $\mathrm{M}^{19}$, Stocks ${ }^{20}$ and Clarke ${ }^{21}$ also supports the same findings as our study that there is no statistical significance between demographic variable gender and locus of control. The reason that may be attributed for lack of any statistical difference could be due to the attitudes of the students which is the same and shows no change with the gender.

This study focuses on the influence of locus of control on the achievement goals of the students. Locus of control is associated with a fear of failure among the students. ${ }^{17}$ The belief of locus of control may be characterized as the two sides of a coin with one side showing the features of external locus of control and the other side depicting the internal locus of control. Locus of control and stress are important determinants of student achievement. There are strategies to be developed to overcome stress of the students about the outcomes of learning and future of life so as to breach the gaps in economic education. Students' academic self-concept also plays a very important role in his or her success in school. It also is a very important predictor of students' academic achievement. ${ }^{10}$ There should be many coping mechanisms utilized by the students to overcome stress. The coping mechanism of the students to reduce stress and improve academic self-concept may be possible if they will have clarity in goals through increased focus on improving knowledge and skills in the field of dentistry. There is a need for a comprehensive orientation program planned for the students including the various factors that can help in controlling stress as majority of them responded to having external locus of 
control which is an indication towards not adapting to stressful situations. Faculty should provide continuous support to all the students specially during the education years where they will be attending dental clinics and working on patients. Students should be made aware of the importance of the various stress mechanisms to shift them from externals to internals.

Locus of control is an expression of a very qualitative measurement of an individual's perception on the various outcomes of their life. Further research should examine factors that are associated with locus of control associated to the academic grades of the students. Grades of the students might help in understanding the gap that may exist between the actual and the perceived outcomes of the students. Research may be replicated among many institutions to ensure generalizability of the study to a larger sample of students.

\section{CONCLUSIONS}

The study participants who responded showed more external locus of control compared to the internal locus of control. Strategies should be planned and tailored to improve student support and student education. They should include a very comprehensive orientation to the students including both long term and short term objectives.

Data sharing statement provided by the authors is available with the full text of this article at jemds.com.

Financial or other competing interests: None.

Disclosure forms provided by the authors are available with the full text of this article at jemds.com.

We are thankful to all the Dentistry program students who have given a consent and participated in our study.

\section{REFERENCES}

[1] Manolis C, Burns DJ, Assudani R, et al. Assessing experiential learning styles: A methodological reconstruction and validation of the Kolb Learning Style Inventory. Learn Individ Differ 2013;23:44-52.

[2] Ponto M, Ooms A, Cowieson F. Learning styles and locus of control in undergraduate medical, nursing and physiotherapy students: a comparative study. Prog Health Sci 2014;4(1):172-8.

[3] Wang Q, Bowling NA, Eschleman KJ. A meta analytic examination of work and general locus of control. J Appl Psychol 2010;95(4):761-8.

[4] Rinn A, Boazman J, Jackson A, et al. Locus of control, academic self-concept and academic dishonesty among high ability college students. J Scholarship Teaching Learning 2014;14(4):88-114.
[5] Rotter JB. Generalized expectancies for internal versus external control of reinforcement. Psychological Monographs 1966;80(1):1-28.

[6] Rotter JB. Some problems and misconceptions related to the construct of internal versus external control of reinforcement. J Consulting Clin Psychol 1975;43(1):5667.

[7] Lefcourt HM. Internal versus external control of reinforcement: a review. Psychol Bull 1966;65(4):206-20.

[8] Rinn AN, Plucker JA, Stocking VB. Fostering gifted students' affective development: a look at the impact of academic self-concept. Teaching Exceptional Chil 2010;6(4):2-13.

[9] Lent RW, Brown SD, Gore PA. Discriminant and predictive validity of academic self-concept, academic self- efficacy and mathematics- specific self- efficacy. J Counseling Psychol 1997;44(3):307-15.

[10] Rinn AN. Trends among honors college students: an analysis by year in school. J Secondary Gifted Educ 2005;16:157-67.

[11] Rinn AN. Effects of programmatic selectivity on the academic achievement, academic self-concepts, and aspirations of gifted college students. Gifted Child Quarterly 2007;51:232-45.

[12] Rotter's locus of control scale. https://www.mccc.edu/ jenningh/Courses/documents /Rotter-locusofcontrolhandout.pdf

[13] Kader AA. Locus of control, student motivation and achievement in principles of microeconomics. Am Int J Contemprary Res 2014;4(9).

[14] Linder F, Janus CE. The relationship of locus of control to academic performance among dental students. Hilton Head, SC: Paper presented at Annual Meeting of the Eastern Educational Research Association February 1997.

[15] Choi N. The effects of test format and locus of control on test anxiety. J College Student Develop 1998;39(6):61620.

[16] Carden R, Briyant C, Moss R. Locus of control, test anxiety, academic procrastination and achievement among college students. Psychol Rep 2004;95(2):581-2.

[17] Burnett JJ. Internal-external locus of control as a moderator of fear appeals. J Appl Psychol 1981;66(3):390-93.

[18] Naik AR. A study on locus of control among college students of Gulbarga City. The International Journal of Indian Psychology. 2015;2(4):47-54.

[19] Mole ML. Satisfaction in adult romantic relationships after parental divorce: the role of locus of control.

[20] Stocks A, April KA, Lynton N. Locus of control and subjective well-being-a cross-cultural study. Problems and perspectives in management. 2012(10, Iss. 1):17-25.

[21] Clarke D. Neuroticism: moderator or mediator in the relation between locus of control and depression? Personality and Individual Differences. $2004 \mathrm{Jul}$ 1;37(2):245-58. 